\title{
A Comparative Assessment on Relative Productivity and Profitability of Chilli under Irrigated and Unirrigated Land in Khargone District of Madhya Pradesh, India
}

\author{
Rahul Birla ${ }^{1}$, N. Khan ${ }^{1}$, Santosh Kumar ${ }^{2 *}$ and Pradeep Patidar ${ }^{1}$ \\ ${ }^{1}$ College of agriculture, Rewa, M.P. India \\ ${ }^{2}$ ICAR-Directorate of Weed Research, Maharajpur, Adhartal, Jabalpur, M.P., India
}

\section{A B S T R A C T}

\begin{tabular}{|l|}
\hline Ke y w o r d s \\
Comparative \\
assessment, \\
Productivity, \\
Profitability, Chilli, \\
Irrigated and \\
unirrigated land \\
\hline Article Info \\
\hline $\begin{array}{l}\text { Accepted: } \\
12 \text { November } 2018 \\
\text { Available Online: } \\
\text { 10 December } 2018\end{array}$ \\
\hline
\end{tabular}

\section{Introduction}

Chilli is considered as one of the commercial spice crops. It is the most widely used universal spice, named as wonder spice. In daily life, chillies are integral and the most important ingredient in many different cuisines around the world as it adds pungency, taste, flavour and colour to the dishes. Indian chilli is considered to be the world famous for two important commercial qualities its colour and pungency levels. Some varieties are famous for the red colour because of the Capsanthin pigment and others are known for biting pungency attributed to capsaicin.
The present study was conducted in Khargone district of Madhya Pradesh. In present study, multi stage sampling technique was used for drawing the sample. Khargone block in Khargone district was selected purposively due to large area under chilli cultivation. From Khargone block 10 villages were selected randomly. From these villages 90 farmers were selected randomly using proportional allocation i.e. small farmer ( $<2$ ha.), medium farmer (2-4 ha.), large farmers ( $>4$ ha.). The primary data was collected from selected respondents using pre-tested questionnaire, through survey method. Each selected respondents was approached personally for recording relevant data. The data was collected for the Agricultural year 2015-2016. Appropriate statistical and economic tools were employed to the collected data. Study revealed that, on an average yield was found to be 4.70 quintal per hectare in irrigated condition over unirrigated and also additional net income Rs.21425 per hectare was found in irrigated condition over unirrigated. Although, the return over per rupee investment was higher in irrigated condition but it is very nominal. 
second largest producer, contributing 9 per cent of total production followed by Orissa (6\%), West Bengal (6\%), Maharashtra (5\%), Madhya Pradesh (4\%) and other States (17\%).

Among the horticultural crops, chilli is one of the important spice produced in Madhya Pradesh. Share of chilli in Chilli all India production is 4 per cent in the state and got rank $6^{\text {th }}$ in the country. Chillies from Madhya Pradesh are well known for their pungency and good red colour. Sagar, Chhindwara, Indore, Dhar, Khargone, Khandwa, Badwani and Burhanpur are the main chilli growing districts in Madhya Pradesh.

Although, the demand of chilli is increasing for export and home consumption, but the present production and productivity of chilli in the country are very inadequate, being only about one-fourth to one-third of the requirement. In order to fulfill the demand of the people, it is essential that the production of chilli should be increased considerably. Chilli is growing in kharif season and during rainy season the irrigation is not a necessary condition for its productivity. But due to erratic rainfall condition and long dry spell condition adequate irrigation is an essential factor for high productivity. Khargone is one of the water scares area. According to environmental profile, only $25 \%$ of ground water potential is being exploited for irrigation. The productivity of chilli is found to be different in irrigated and un-irrigated condition due to weather condition. This would also affect the time and quantity of inputs requirements in irrigated and unirrigated chilli growing in the area. The problems of chilli growers are numerous but the main is realizing low productivity with utilization of scarce resource. The study is expected to throw some light on profitability of cultivation practices of the chilli crop with irrigated and unirrigated condition. The farmers spend the scare capital in production technology according to level of profitability, needs a critical analysis of cost involved in production and level of return realized. It is also realized that major problem of chilli development is how to make the efficient utilization of farm resources.

\section{Materials and Methods}

For the study, a multi stage sampling technique was employed in selection of the block, villages and sample. Khargone block in Khargone district was selected purposively due to large area under chilli cultivation and well known area by researcher which was made convenience in data collection. From this block, ten villages selected were selected randomly. The sample size for the study was 90 farmers randomly selected from tem villages. The samples were drawn from the list of farmers according to the size of land holding, who having more area under chilli crop to their total cropped area. The chilli producing farmers were categorized as small ( $<2$ ha.), medium (2 to 4 ha.) and large (above 4 ha.), based on land holding size of the farmers. The data on different aspects were collected through pre-tested interview schedule. Each of the selected sample chilli growers was approached personally for recording relevant data. The data were collected using survey method. All the collected primary data was related to the agriculture year 2015-16, kharif seasons.

\section{Analytical procedure}

Collected data were edited and checked for their adequacy and accuracy. Keeping in view classified and tabulated data were further processed in terms of average and percentage to arrive at conclusive figures for interpretation of data. In present study following statistical and econometrics tools were used. 


\section{Cost concepts}

The cost of cultivation classified as recommended, "Special expert committee on cost estimates, GOI, New Delhi", was used in this study.

The cost concepts are given below:

Cost $\mathbf{A}_{1:}$ It includes:

Value of hired human labour,

Value of hired and owned bullock labour, Value of hired and owned machinery labour, Value of owned and purchased seed, Value of fertilizers, manures and chemical, Value of insecticide and pesticides, Expenditure on irrigation, Land revenue and taxes, Interest paid on crop loan if taken, Depreciation on farm assets excluding land, Interest on working capital, Miscellaneous expenses.

Cost $\mathbf{A}_{2}$ : It includes:

Cost A1 + rent paid for leased in land

Cost $\mathbf{B}_{1}$ : It includes:

Cost A2 + interest on value of owned fixed capital assets. (excluding land)

Cost $\mathbf{B}_{2}$ : It includes:

Cost $\mathrm{B} 1+$ rental value of owned land

Cost $\mathbf{C}_{1}$ : It includes:

Cost B1+ imputed value of family labour

Cost $\mathrm{C}_{2}$ : It includes:

Cost B2 +imputed value of family labour

Cost $\mathbf{C}_{3}$ : Cost $\mathrm{C} 2+10$ percent of cost $\mathrm{C} 2$ to account for managerial input of the farmer.

\section{Results and Discussion}

Socio economic structure of chilli growers

Socio economic status of chilli growers is one of the factors responsible for level of inputs and technology used at farm level and this makes effective the managerial power effective in decision making process to get maximum farm profit from their farm. This comprises of personnel characteristics of farmers, structure of family and structure of farm respectively. Hence, it is pertinent to assess the characteristic of the respondents as below.

\section{a. Age and education level of chilli growers}

The chilli growers generally take the important decision on the farm business with reference to input use, cropping pattern and other farm management practices which are influenced by the level of education and experienced gained by the chilli growers with their length of age. Therefore, it is pertinent to have an idea regarding the age and education level of the chilli growers. The data on distribution of chilli growers according to age and education level has been presented in Table 1.

\section{Age of chilli growers}

The age factor plays an important role with working long hours and hard work in one way and decision making capacity in another way. The Table 1 revealed that the average age of chilli growers was found to be 44 years. The minimum age of chilli grower found to be 21 year age and the maximum year of chilli growers was found to be 72 years. In case of small chilli growers age was be of average found to 44 years of average age followed by 46 years and 43 years of age in case of medium and large chilli growers respectively. 


\section{Education of chilli growers}

Education is associated with direct bearing on the farming as it is viable for a quick and thorough adoption of improved technology. However, it might be depending upon the quality and nature of education and training. Data revealed that on average $(38.89 \%)$ chilli growers were illiterate, while remaining $(61.11 \%)$ chilli growers were literate.

The Table 1 presented the distribution of the chilli growers as per level of education in different size of holding. The data revealed that the higher literacy positions were found to be in case of large farmers $(25.00 \%)$ followed by $(20.00 \%)$ in case of medium farmers and $(16.67 \%)$ in case of small farmers respectively. This shows that higher literacy position was found to increase with increase in size of holding.

\section{Average size of family and work force}

Size of farm family and available work force in a family are considered to be a factor influencing economic status. Family is one unit, which includes the total number of members to cultivate the given operational area. The detail of family has been presented in Table 2.

The revealed that, the average size of family of chilli growers was found to be 6.58 persons per holding. Study reveals that the size of family was found to increase with increasing size of holding. In this way, in case of small chilli growers the average size of family found to 6.45 persons per farm followed by 6.61 persons and 6.69 persons in case of medium and large chilli growers respectively.

The distribution of family working force revealed that the average number of active members was found to be 3.15 people per farm. These persons are per farming so many farm and other activities for earning family income. Study revealed that the higher numbers of workers were found in medium size of holding i.e. 3.23 persons per family followed by 3.16 and 3.06 persons in case of large and small chilli growers respectively.

\section{Land use and irrigation pattern}

Since, the economic profitability of chilli cultivation was assessed in the irrigated and unirrigated condition. Hence, the small, medium and large size of chill growers was further subdivided into irrigated and unirrigated chilli growers as per availability of irrigation facilities with the chilli growers. The detail of land use pattern is prescribed same into two sub division of irrigated and unirrigated situation. The land use and irrigation pattern has been presented in Table 3.

As observed from the table, the average size of holdings in case of irrigated small chilli growers was found to be 1.34 hectare per farm. On the other hand, the average size of holdings in case of unirrigated small chilli growers was found to be 1.31 hectare per farm. The average size of holdings in case of irrigated medium chilli growers was found to be 3.31 hectare per farm. On the other hand, the average size of holdings in case of unirrigated medium chilli growers was found to be 3.45 hectare per farm. The average size of holdings in case of irrigated large chilli growers was found to be 8.97 hectare per farm. On the other hand, the average size of holdings in case of unirrigated large chilli growers was found to be 9.09 hectare per farm.

The average cultivated area in case of irrigated small chilli growers was found to be 1.28 hectare per farm. On the other hand, the average cultivated area in case of unirrigated small chilli growers was found to be 1.24 hectare per farm. The average cultivated area in case of irrigated medium chilli growers was 
found to be 3.20 hectare per farm. On the other hand, the average cultivated area in case of unirrigated medium chilli growers was found to be 3.29 hectare per farm. The average cultivated area in case of irrigated large chilli growers was found to be 8.74 hectare per farm. On the other hand, the average cultivated area in case of unirrigated large chilli growers was found to be 8.86 hectare per farm.

The irrigation is the important source for enhancing the cultivated area in the form of double cropping system and also enhancing the productivity of crops per unit of area. The small irrigated chilli growers have 0.75 hectare per farm as irrigated land followed by medium irrigated chilli growers have 1.69 hectare per farm as irrigated land and large irrigated chilli growers have 5.52 hectare per farm as irrigated land. The area under chilli is important among the existing cropping pattern of chilli growers under study. On an average the chilli area in case of irrigated small chilli growers was found to be 0.75 hectare per farm. On the other hand, the average chilli area in case of unirrigated small chilli growers was found to be 0.67 hectare per farm. The average chilli area in case of irrigated medium chilli growers was found to be 1.90 hectare per farm. On the other hand, the average chilli area in case of unirrigated medium chilli growers was found to be 1.96 hectare per farm. The average chilli area in case of irrigated large chilli growers was found to be 2.85 hectare per farm. On the other hand, the average chilli area in case of unirrigated large chilli growers was found to be 2.90 hectare per farm.

\section{Cost of cultivation of chilli in irrigated and unirrigated land}

The detail of cost structure of chilli cultivation on irrigated and unirrigated farm in different size of holding has been presented in Table 4 and 5.
The data on cost of cultivation of chilli under irrigated condition shows that on an average cost of cultivation per hectare of chilli crop was found to Rs.21631 (Cost $\mathrm{A}_{1}$ ) followed by Rs.21795 (Cost $\mathrm{B}_{1}$ ), Rs.26795 (Cost $\mathrm{B}_{2}$ ), Rs.35062 (Cost $\left.\mathrm{C}_{1}\right)$, Rs.40062 (Cost $\left.\mathrm{C}_{2}\right)$ and Rs.44068 (Cost $\mathrm{C}_{3}$ ) respectively. In this study cost $\mathrm{A}_{2}$ was not under taken due to that all the chilli growers were used their own land.

Estimation of operational cost (cost $\mathrm{A}_{1}$ ) revealed that, in irrigated condition the average operational cost i.e. cost $A_{1}$ was higher on large farms being Rs.23613 per hectare and lowest was found with small chilli growers i.e. Rs.18866 per hectare. On the other hand the operational cost on medium chilli growers was accounted to Rs.22415 per hectare. The study depicted that in irrigated condition the cost $A_{1}$ was found to increase with increasing size of holding. The higher cost with higher size of holding was due to used of hired human labour on their farm.

The total cost estimates i.e. cost $\mathrm{C}_{1}, \mathrm{C}_{2}$ and $\mathrm{C}_{3}$ based on the imputed values would give and unrealistic and even misleading picture of costs. It is attributable to the fact that chilli growers try to minimize only out of pocket expenses of cultivation and that by and large, they make maximum use of resources they own, but it is also not justifiable to take into account only paid out cost. To determine the cost structure in irrigated condition $\operatorname{cost} \mathrm{C}_{1}, \mathrm{C}_{2}$ and $\mathrm{C}_{3}$ were also analyzed in present study. The maximum cost $\mathrm{C}_{3}$ in irrigated condition was found Rs.45005 in case of small chilli growers followed by Rs.44129 on large chilli growers farm and Rs.43069 by medium chilli growers respectively. This shows that medium chilli growers used efficient practices and inputs in production process and small chilli growers used comparatively injudicious inputs in production process.

The detail of cost structure of chilli cultivation on unirrigated farm in different size of holding is presented in Table 5. 
Cost of cultivation of chilli under unirrigated condition shows that, on an average cost of cultivation per hectare of chilli crop was found to be Rs.18700 (Cost A1) followed by Rs.18850 (Cost B1), Rs.22350 (Cost B2), Rs.31050 (Cost C1), Rs.34550 (Cost C2) and Rs.38005 (Cost C3) respectively. In this study cost A2 was not under taken due to that all the chilli growers were used their own land.

Cost A1 estimated that, higher on medium farms being Rs.20443 per hectare and lowest was found with small chilli growers i.e. Rs. 15475 per hectare in unirrigated.

On the other hand the operational cost on large chilli growers was accounted to Rs.20183 per hectare in large farm. The higher cost A1 in unirrigated condition with medium size of holding was due to used of proportionally higher number of hired human labour on their farm.

The maximum cost $\mathrm{C} 3$ in unirrigated condition was found Rs.38440 in case of large chilli growers followed by Rs.37872 on small chilli growers farm and Rs.37704 by medium chilli growers respectively. This shows that in unirrigated condition medium chilli growers used efficient practices and inputs in production process and small chilli growers used comparatively injudicious inputs in production process.

\section{Productivity of chilli production on irrigated and unirrigated land}

The productivity and production under irrigated and unirrigated condition of chilli cultivation has been presented in Table 6 .

The yield per hectare of chilli found to variation in different situation i.e. irrigated and unirrigated condition. The yield per unit of area also found to variation in different size of farm. The average yield on irrigated condition farm was found to be 33.95 quintal per hectare as a green chilli. On the other hand, the average yield on unirrigated condition farm was found to be 23 quintal per hectare as a green chilli.

The average yield on different size of holding in irrigated condition, data shows it was found to maximum 34.93 quintal per hectare on large size of holding followed by 33.89 quintal per hectare on small size of holding and 33.02 quintal per hectare on medium size of holding.

The average yield on different size of holding in unirrigated condition, data shows it was found to maximum 23.50 quintal per hectare on small size of holding followed by 23.25 quintal per hectare on medium size of holding and 22.25 quintal per hectare on large size of holding.

The above data shows that the medium farmers realized minimum yield on per unit of area in both the condition and it might be due to uneconomic scale of production.

\section{Profitability from chilli in irrigated and unirrigated land}

Table 7 revealed that, the gross income per hectare of chilli production under irrigated condition received variation by different size group. This was due to different quantity of yield per unit of area and market price received on the basis of quality of crop, places of marketing and time of disposal.

The overall gross income per hectare of chilli crop in case of irrigated condition was found to Rs.83261 per hectare. The maximum gross return under irrigated chilli cultivation was realized by large chilli growers Rs.84893 per hectare followed by small chilli growers Rs.83248 per hectare and medium chilli growers Rs.81643 per hectare. 
Table.1 Distribution of chilli growers as per their age and education level in different size of holding

(Average number of person per farm)

\begin{tabular}{|l|c|c|c|c|}
\hline \multirow{2}{*}{ Description } & \multicolumn{4}{|c|}{ Size of holding } \\
\cline { 2 - 5 } & Small & Medium & Large & Average \\
\hline Average Age group (year) & 44 & 46 & 43 & 44 \\
\hline Minimum and maximum age group & $21-70$ & $28-71$ & $26-72$ & $21-72$ \\
\hline Education level & & & & \\
\hline Illiterate & 7 & 16 & 12 & 35 \\
\hline Upto primary & $(38.89)$ & $(40.00)$ & $(37.50)$ & $(38.89)$ \\
\hline Upto middle & 5 & 10 & 8 & 23 \\
& $(27.78)$ & $(25.00)$ & $(25.00)$ & $(25.56)$ \\
\hline Upto high school and above & 3 & 6 & 4 & 13 \\
& $(16.67)$ & $(15.00)$ & $(12.50)$ & $(14.44)$ \\
\hline Total & 3 & 8 & 8 & 19 \\
& $(16.67)$ & $(20.00)$ & $(25.00)$ & $(21.11)$ \\
\hline
\end{tabular}

Note: Data presented in parentheses shows percentage to total.

Table.2 Distribution of strength and work force in different size of holding

(Average number of person per farm)

\begin{tabular}{|l|c|c|c|c|}
\hline \multicolumn{1}{|c|}{ Family description } & \multicolumn{4}{c|}{ Size of holding } \\
\hline Strength & Small & Medium & Large & Average \\
\hline Male & 1.89 & 2.05 & 2.06 & 2.00 \\
\hline Female & 1.50 & 1.68 & 1.66 & 1.61 \\
\hline Children & 3.06 & 2.88 & 2.97 & 2.97 \\
\hline Total & 6.45 & 6.61 & 6.69 & 6.58 \\
\hline Work force & & & & \\
\hline Male & 1.67 & 1.80 & 1.75 & 1.74 \\
\hline Female & 1.39 & 1.43 & 1.41 & 1.41 \\
\hline Total & 3.06 & 3.23 & 3.16 & 3.15 \\
\hline
\end{tabular}

Table.3 Land use and irrigation pattern of different size of holding

(ha/farm)

\begin{tabular}{|c|c|c|c|c|c|c|}
\hline \multirow{2}{*}{ Particulars } & \multicolumn{3}{|c|}{ Irrigated farm } & \multicolumn{3}{c|}{ Unirrigated farm } \\
\hline & Small & Medium & Large & Small & Medium & Large \\
\hline Size of holdings & 1.34 & 3.31 & 8.97 & 1.31 & 3.45 & 9.09 \\
\hline Cultivated area & 1.28 & 3.20 & 8.74 & 1.24 & 3.29 & 8.86 \\
\hline Irrigated area & 0.75 & 1.69 & 5.52 & 0 & 0 & 0 \\
\hline Kharif crops & 1.25 & 3.06 & 8.52 & 1.14 & 3.15 & 8.70 \\
\hline Followed land & 0.03 & 0.13 & 0.22 & 0.12 & 0.14 & 0.16 \\
\hline Rabi crops & 1.06 & 2.48 & 6.51 & 0.94 & 2.50 & 6.73 \\
\hline Gross cropped area & 2.32 & 5.55 & 15.03 & 2.09 & 5.65 & 15.44 \\
\hline Area under chilli & 0.75 & 1.90 & 2.85 & 0.67 & 1.96 & 2.90 \\
\hline
\end{tabular}


Table.4 Cost of cultivation of chilli crop under irrigated farm in different size of holding (Rs/ha)

\begin{tabular}{|c|c|c|c|c|c|}
\hline \multirow[t]{2}{*}{ S.No. } & \multirow[t]{2}{*}{ Cost particulars } & \multicolumn{4}{|c|}{ Size of farm (Irrigated area) } \\
\hline & & Small & Medium & Large & Average \\
\hline 1. & Hired human labour & 0 & 4800 & 5600 & 3467 \\
\hline 2. & Bullock labour & 1500 & 1800 & 2100 & 1800 \\
\hline 3. & Machine power & 2000 & 1500 & 2000 & 1833 \\
\hline 4. & Seed & 5651 & 5701 & 5589 & 5647 \\
\hline 5. & Fertilizer +manure & 3506 & 3511 & 3724 & 3580 \\
\hline 6. & Plant protection & 1958 & 1856 & 2252 & 2022 \\
\hline 7. & Irrigation & 1242 & 1231 & 1038 & 1170 \\
\hline 8. & Interest on working capital & 330 & 425 & 465 & 407 \\
\hline 9. & Depreciation & 2482 & 1389 & 629 & 1500 \\
\hline \multirow[t]{2}{*}{10.} & Land revenue & 197 & 202 & 216 & 205 \\
\hline & Cost- $\mathrm{A}_{1}$ & 18866 & 22415 & 23613 & 21631 \\
\hline \multirow[t]{2}{*}{11} & Interest on fixed capital & 248 & 139 & 104 & 164 \\
\hline & Cost-B $\mathrm{B}_{1}$ & 19114 & 22554 & 23717 & 21795 \\
\hline \multirow[t]{2}{*}{12.} & Rental value of land & 5000 & 5000 & 5000 & 5000 \\
\hline & Cost- $\mathrm{B}_{2}$ & 24114 & 27554 & 28717 & 26795 \\
\hline \multirow[t]{4}{*}{13.} & Imputed value of family labour & 16800 & 11600 & 11400 & 13267 \\
\hline & Cost- $\mathrm{C}_{1}$ & 35914 & 34154 & 35117 & 35062 \\
\hline & Cost- $\mathrm{C}_{2}$ & 40914 & 39154 & 40117 & 40062 \\
\hline & Cost- $\mathrm{C}_{3}$ & 45005 & 43069 & 44129 & 44068 \\
\hline
\end{tabular}

Table.5 Cost of cultivation of chilli crop under unirrigated farm in different size of holding

\begin{tabular}{|c|c|c|c|c|c|}
\hline \multirow[t]{2}{*}{ S.No. } & \multirow[t]{2}{*}{ Particulars } & \multicolumn{4}{|c|}{ Size of farm (Unirrigated area) } \\
\hline & & Small & Medium & Large & Average \\
\hline 1. & Hired human labour & 0 & 4400 & 4600 & 3000 \\
\hline 2. & Bullock labour & 1200 & 1800 & 2100 & 1700 \\
\hline 3. & Machine power & 1500 & 1500 & 1500 & 1500 \\
\hline 4. & Seed & 5401 & 5695 & 5417 & 5504 \\
\hline 5. & Fertilizer +manure & 2808 & 3327 & 3199 & 3111 \\
\hline 6. & Plant protection & 1668 & 1896 & 2240 & 1935 \\
\hline 7. & Irrigation & 0 & 0 & 0 & 0 \\
\hline 8. & Interest on working capital & 262 & 388 & 397 & 349 \\
\hline 9. & Depreciation & 2539 & 1332 & 621 & 1497 \\
\hline \multirow[t]{2}{*}{10.} & Land revenue & 97 & 105 & 109 & 104 \\
\hline & Cost- $\mathrm{A}_{1}$ & 15475 & 20443 & 20183 & 18700 \\
\hline \multirow[t]{2}{*}{11} & Interest on fixed capital & 254 & 133 & 62 & 150 \\
\hline & Cost- $\mathrm{B}_{1}$ & 15729 & 20576 & 20245 & 18850 \\
\hline \multirow[t]{2}{*}{12.} & Rental value of land & 3500 & 3500 & 3500 & 3500 \\
\hline & Cost- $\mathrm{B}_{2}$ & 19229 & 24076 & 23745 & 22350 \\
\hline \multirow[t]{4}{*}{13.} & Imputed value of family labour & 15200 & 10200 & 11200 & 12200 \\
\hline & Cost- $\mathrm{C}_{1}$ & 30929 & 30776 & 31445 & 31050 \\
\hline & Cost $-C_{2}$ & 34429 & 34276 & 34945 & 34550 \\
\hline & Cost- $C_{3}$ & 37872 & 37704 & 38440 & 38005 \\
\hline
\end{tabular}


Table.6 Productivity of chilli crop under irrigated and unirrigated farm in different size of holding

\begin{tabular}{|c|l|c|c|c|c|}
\hline S.No. & \multicolumn{4}{|c|}{ Cost particulars } & \multicolumn{4}{|c}{ Size of farm } \\
\cline { 3 - 6 } & & Small & Medium & Large & Average \\
\hline 1. & Green chilli yield $(\mathbf{q} /$ ha.) Irrigated & 33.89 & 33.02 & 34.93 & 33.95 \\
\hline 2. & Green chilli yield (q/ha.) Unirrigated & 23.50 & 23.25 & 22.25 & 23 \\
\hline
\end{tabular}

Table.7 Profitability of chilli crop on irrigated farm in different size of group

\begin{tabular}{|c|l|c|c|c|c|}
\hline S.No. & \multicolumn{2}{|c|}{ Return particulars } & \multicolumn{3}{c|}{ Size of farm (Irrigated area) } \\
\hline $\mathbf{1}$ & Cost C & 45005 & 43069 & 44129 & 44068 \\
\hline $\mathbf{2}$ & Gross income & 83248 & 81643 & 84893 & 83261 \\
\hline $\mathbf{3}$ & Net income & 38243 & 38574 & 40764 & 39194 \\
\hline $\mathbf{4}$ & Family labour income & 59134 & 54089 & 56176 & 56466 \\
\hline $\mathbf{5}$ & Farm business income & 64382 & 59228 & 61280 & 61630 \\
\hline $\mathbf{6}$ & Sale price & 2456.41 & 2472.53 & 2430.37 & 2452.45 \\
\hline $\mathbf{7}$ & B.C. Ratio & 1.85 & 1.90 & 1.92 & 1.89 \\
\hline
\end{tabular}

Table.8 Profitability of chilli crop on unirrigated farm in different size of group

\begin{tabular}{|r|l|c|c|c|c|}
\hline S.No. & \multicolumn{2}{|c|}{ Return particulars } & \multicolumn{3}{c|}{ Size of farm (Unirrigated area) } \\
\cline { 3 - 6 } & & Small & Medium & Large & Average \\
\hline $\mathbf{1}$ & Cost $\mathrm{C}_{3}$ & 37872 & 37704 & 38440 & 38005 \\
\hline $\mathbf{2}$ & Gross income & 56987 & 56381 & 53956 & 55775 \\
\hline $\mathbf{3}$ & Net income & 19115 & 18677 & 15516 & 17769 \\
\hline $\mathbf{4}$ & Family labour income & 37758 & 32305 & 30211 & 33425 \\
\hline $\mathbf{5}$ & Farm business income & 41552 & 35938 & 33773 & 37088 \\
\hline $\mathbf{6}$ & B.C. Ratio & 1.50 & 1.49 & 1.40 & 1.46 \\
\hline
\end{tabular}

Table.9 Average productivity and profitability of chilli crop on irrigated and unirrigated farm

\begin{tabular}{|r|l|c|c|c|}
\hline S.No. & \multicolumn{1}{|c}{ Particulars } & Irrigated & Unirrigated & Increased over unirrigated \\
\hline $\mathbf{1}$ & Yield q/ha. & 33.95 & 23 & 10.95 \\
\hline $\mathbf{2}$ & Gross income & 83261 & 55775 & 27486 \\
\hline $\mathbf{3}$ & Net income & 39194 & 17769 & 21425 \\
\hline $\mathbf{4}$ & Family labour income & 56466 & 33424 & 23042 \\
\hline $\mathbf{5}$ & Farm business income & 61630 & 37088 & 24542 \\
\hline $\mathbf{6}$ & B.C. Ratio & 1.89 & 1.46 & 0.43 \\
\hline
\end{tabular}


The net income is the real income realized by chilli growers and it was found to on an average Rs.39194 per hectare. The maximum net return under irrigated chilli cultivation was realized by large chilli growers Rs.40764 per hectare followed by medium chilli growers Rs.38574 per hectare and small chilli growers Rs.38243 per hectare. The trend of net income revealed that it was increased with increasing size of holding.

The other profitability measures revealed that on an average the chilli growers realized by Rs.56466 per farm as family labour income and Rs.61630 per farm as farm business income in irrigated condition.

The B.C. ratio determines return over per rupee investment. Data revealed that in irrigated condition the chilli growers realized on an average 1.89 as B.C. ratio in chilli production. The B.C. ratio was found to variation in different size of holding and it was maximum 1.92 in large size group followed by 1.90 with medium size and 1.85 with small size of chilli growers. This indicated that the B.C. ratio of irrigated chilli cultivation found to increase with increasing size of holding. The profitability of chilli per hectare at different profitability measures on unirrigated farms are presented in Table 8.

Gross income per hectare of chilli production under unirrigated condition received variation by different size group. This was due to different quantity of yield per unit of area and market price received on the basis of quality of crop, places of marketing and time of disposal. The overall gross income per hectare of chilli crop in case of unirrigated condition was found to Rs.55775 per hectare. The maximum gross return under unirrigated chilli cultivation was realized by small chilli growers Rs.56987 per hectare followed by medium chilli growers Rs.56381 per hectare and large chilli growers Rs.53956 per hectare.
The trend of gross return revealed that it was increased with increasing size of holding.

The net income is the real income realized by chilli growers and it was found to on an average Rs.17769 per hectare. The maximum net return under unirrigated chilli cultivation was realized by small chilli growers Rs. 13115 per hectare followed by medium chilli growers Rs.18677 per hectare and large chilli growers Rs.15516 per hectare. The trend of net income revealed that it was increased with increasing size of holding.

The other profitability measures revealed that on an average the chilli growers realized by Rs.33425 per farm as family labour income and Rs.37088 per farm as farm business income in unirrigated condition.

The B.C. ratio determines return over per rupee investment. Data revealed that in unirrigated condition the chilli growers realized on an average 1.46 as B.C. ratio in chilli production. The B.C. ratio was found to variation in different size of holding and it was maximum 1.50 in small size group followed by 1.49 with medium size and 1.40 with large size of chilli growers. This indicated that the B.C. ratio of unirrigated chilli cultivation found to decreasing with increasing size of holding.

\section{Comparative analysis of productivity and profitability of chilli under irrigated and unirrigated condition}

Study revealed that, on an average chilli growers realized additional yield 4.70 quintal per hectare in irrigated condition over unirrigated. On the other hand, the chilli growers also realized additional net income of Rs.21425 per hectare in irrigated condition over unirrigated. Although, the return over per rupee investment was higher in irrigated condition but it is very nominal (Table 9). 
It is concluded on the basis of above discussion, chilli growers in irrigated condition was better than unirrigated chilli growers because of availability of irrigation facilities. Study revealed that, the chilli growers could be realized higher productivity and higher profitability in irrigated condition over unirrigated condition. Hence, the policy makers, development agencies and farmers should manage to increase irrigation facilities in the area to boost-up the yield and economic condition of chilli growers.

\section{References}

Ahmad T, Bathla HVL, Rai A, Mathur DC and Sood RM. 2011. An alternative methodology for estimation of area and production of horticultural crops. Model Assist. Statistic Apply., Vol .6, No.4, Pp 325-336.

BC Rajur, BI Patil and H Basavaraj 2008. Economics of Chilli Production in Karnataka. Karnataka J. Agric. Sci., 21(2) : 237-240.

Deore SG, Pawar PP and Pulate SL. 2015. Economics of marketing of Green Chilli in Western Maharashtra. Internat. J. Appl. Soc. Sci., 2 (3\&4) : 84.

Elayutham LKV and Damodaran K. 2015. Growth Rate of Chilli Production in Guntur District of Andhra Pradesh. International Journal of Research in Humanities and Social Studies, Volume 2, Issue 11, November 2015, PP 1-5.

Hanumanaika, Jadhav RH, Ashalatha SN and Hind KV. 2009. Extent of adoption of recommended technology by the chilli growers in Tunga Bhadra Project area of Bellary district of Karnataka. AgriHorticultural (Muzaffarnagar). 32(4):367-370.

Jadav K.S, Patel jisnu K. and Parmar H.C.(2014) comparative economics of green chilli cultivation under drip and conventional irrigation methods - a case study of middle Gujarat, international journal of agricultural sciences Vol. 2

Jagtap PP, Shingane US and Kulkarni KP. 2012. Economics of Chilli Production in India Department of Agricultural Economics and Statistics, K.K. Wagh College of Agriculture Business Management, Nashik, India Department of Agricultural Economics and Statistics, Shri Shivaji Agriculture College, Amravati, India.

Korikanthinath VS, Rao Govardhan, Hiremath GM, Peter KV and Rao G. 2000. Resource productivities and their optimum utilization pattern in chilli based mixed cropping system $-A n$ Economic analysis, 57(1):83-86.

Madariya Rajesh 2015. Economic analysis of green chilli production under different technological status of farms in Dhar district of Madhya Pradesh. M.Sc. (Agri.) Thesis Submitted to Rajmata Vijayaraje Scindia Krishi Vishwa Vidyalaya, Gwalior.

Mohammed B, Abdulsalam Z and Ahmed B. 2015. Profitability in Chilli Pepper Production in Kaduna State, Nigeria Institute for Trypanosomiasis Research (NITR), Kaduna, Nigeria. Department of Agricultural Economics and Rural Sociology, Faculty of Agriculture, Ahmadu Bello University, Zaria, Kaduna State, Nigeria.

Mondloi KS. 2006. Farm profitability and resource use efficiency in cultivation of chilli in Dhar District, Madhya Pradesh. M.Sc. (Agril. Econ.) Submitted to J.N.K.V.V. Jabalpur.

Olayiwola O. 2014. An economic analysis of chilli crop production in ilora area of oyo state. International Monthly Refereed Journal of Research In Management \& Technology, Volume III, January'14

Rajur BC, Patil BL and Basavaraj H. 2008. Economic analysis of chilli production 
in Raichur, Bijapur and Gulbarga districts. University of Agricultural Sciences, Dharwad Karnataka J. Agric. Sci., 21(2): (237-240).

Sreedhara DS, Kerutagi MG, Basavaraja H, Kunnal LB, Dodamani MT. 2013. Economics of capsicum production under protected condition. Kittur Rani Channamma College of Horticulture,
Arabhavi Karnataka Journal Agricultural Sciences 26(2):(217-219).

Vithob B and Gayatri Y. 2011. Economics of chilli crop cultivation in Indian agriculture- A study in upper Krishna project area (Karnataka), International Research Journal agricultural Economics \& Statistics, 2 (1): 28-30.

\section{How to cite this article:}

Rahul Birla, N. Khan, Santosh Kumar and Pradeep Patidar. 2018. A Comparative Assessment on Relative Productivity and Profitability of Chilli under Irrigated and Unirrigated Land in Khargone District of Madhya Pradesh. Int.J.Curr.Microbiol.App.Sci. 7(12): 1571-1582. doi: https://doi.org/10.20546/ijcmas.2018.712.185 